https://doi.org/10.15407/dopovidi2021.04.094

УдК 57.044: 616.361-002.2+612.111.11+616.155.1-3+616.155.153

I.В. Бєлінська, https://orcid.org/0000-0003-3551-1161

Г.М. Кузнєцова, https://orcid.org/0000-0002-1296-1007

Н.В. Дзюбенко, https://orcid.org/0000-0002-2998-4168

Ю.В. Савич

Д.С. Мілохов, https://orcid.org/0000-0002-7493-3634

О.В. Хиля, https://orcid.org/0000-0002-1155-0740

\title{
Т.В. Рибальченко
}

Київський національний університет ім. Тараса Шевченка E-mail: byelinska@univ.kiev.ua

\section{Застосування 1-(4-Cl-бензил)-3-Cl-4-( $\mathrm{CF}_{3}$-феніламіно)- $1 H$-пірол-2,5-діону як панспецифічного інгібітора протеїнкіназ для гальмування гематологічних ускладнень на тлі експериментального хронічного холангіту у щурів}

\author{
Представлено членом-кореспондентом НАН Украйни Р.С. Стойкою
}

Досліджено вплив панспецифічного інгібітора протеїнкіназ похідного піролу (1-(4-Cl-бензил)-3-Cl-4-(CF феніламіно)-1Н-пірол-2,5-Әіон (МI-1)), синтезованого в Київському національному університеті ім. Тараса Шевченка, на гематологічні прояви експериментального хронічного холангіту, індукованого а-нафтилізотіоціанатом. Встановлено, що МI-1 зменшує рівень запального процесу, що підтверджується нормалізацією загальної кількості лейкоцитів у крові внаслідок зменшення кількості еозинофільних і нейтрофільних гранулоцитів та лімфоцитів, які залучені до розвитку експериментального хронічного холангіту. МI-1 відновлює кількість еритроцитів у крові шляхом активації еритропоезу, що підтверджується зростанням кількості ретикулоцитів у крові. Введення МI-1 сприяє нормалізащї кількості тромбоцитів у крові, найвірогідніше, через пригнічення утворення тромбоцитів у кістковому мозку, активованого розвитком запального процесу в печіниі. Під впливом МI-1 зменшується рівень гематологічних ускладнень, що зумовлені експериментальним хронічним холангітом. Зважаючи на це і доведену низьку загальну гематоксичність та гепатопротективну дію MI-1 є перспективним для подальших досліджень як сполука з протизапальною активністю.

Ключові слова: похідне піролу, інгібітор протеӥнкіназ, хронічний холангіт, еритроцити, лейкоцити, тромбоцити.

Цитування: Бєлінська І.В., Кузнєцова Г.М., Дзюбенко Н.В., Савич Ю.В., Мілохов Д.С., Хиля О.В., Рибальченко Т.В. Застосування 1-(4-Cl-бензил)-3-Cl-4-( $\mathrm{CF}_{3}$-феніламіно)-1Н-пірол-2,5-діону як панспецифічного інгібітора протеїнкіназ для гальмування гематологічних ускладнень на тлі експериментального хронічного холангіту у щурів. Допов. Нащ. акад. наук Укр. 2021. № 4. С. 94-102. https://doi.org/10.15407/ dopovidi2021.04.094 
Застосування 1-(4-Cl-бензил)-3-Cl-4-(CF - -еніламіно)-1Н-пірол-2,5-діону як панспещифічного інгібітора...

Хронічний холангіт належить до запальних захворювань печінки, який виникає внаслідок розвитку запалення жовчних шляхів і, як результат цього процесу, закінчується деструкцією і фіброзом жовчних проток [1]. Холангіоцити активно секретують прозапальні цитокіни. У цих клітинах зростає експресія IL-6 і IL-8, рівень фактору некрозу пухлин альфа (TNF- $\alpha)$, хемокінового ліганду CX3CL1 та інших цитокінів [2]. Надмірна секреція і експресія прозапальних цитокінів спричинює міграцію і акумулювання лейкоцитів навколо печінкових проток, порушення функції холангіоцитів, гальмування $\mathrm{Cl}^{-} / \mathrm{HCO}_{3}^{-}$-аніонного обмінника, зменшення резистетності цих клітин до жовчних кислот і загибель холангіоцитів шляхом апоптозу. Внаслідок активації прозапальними цитокінами проліферації фібробластів і продукції позаклітинного матриксу відбувається розростання сполучної тканини і заміщення нею жовчних шляхів. Порушення епітеліальної вистілки жовчних проток зумовлює застій жовчі, розвиток портальної гіпертензії і, як наслідок, пошкодження клітин печінки, підшлункової залози, нирок та інших органів, проявом чого є підвищення загального білірубіну, креатиніну, активності аланінамінотрансферази, аспартатамінотрансферази, лужної фосфатази і лактатдегідрогенази в сироватці крові [3].

До розвитку холангіту залучаються і клітини крові. Ініціація запалення в біліарних трактах спричинює активну міграцію лейкоцитів до тканини печінки і супроводжується зміною їх кількості та розподілу в крові [1]. Запальний процес індукує виникнення і прогресування анемії, яка розвивається внаслідок внутрішніх кровотеч у зоні ураження, активації мононуклеарних фагоцитів і надмірної деструкції еритроцитів у селезінці, порушення транспорту заліза і вітаміну $\mathrm{B}_{12}$ у кишечнику, пригнічення продукції еритроцитів у кістковому мозку внаслідок впливу прозапальних цитокінів на гемопоетичні клітини тощо [4].

Лікування хронічного холангіту спрямовано на зниження рівня запалення в жовчних протоках і в тканині печінки та покращення відтоку жовчі. Одним із іноваційних підходів у лікуванні холангіту є пригнічення проліферації і функціональної активності клітин сполучної тканини для зменшення рівня фіброзу, для чого використовують різної природи інгібітори сигнальних шляхів, які залучені до цих процесів [1]. До таких інгібіторів належить і похідне піролу MI-1 (1-(4-Cl-бензил)-3-хлор-4-( $\mathrm{CF}_{3}$-феніламіно)-1H-пірол-2,5-діон), що синтезоване в Київському національному університеті ім. Тараса Шевченка і є інгібітором низки протеїнкіназ. Оскільки в попередніх дослідженнях показано, що МI-1 сприяє частковій корекції печінкової недостатності, спричиненої гострим холангітом [5], а клітини крові є індикатором стану організму, стадії захворювання і відповіді на терапію [3], метою нашого дослідження було вивчення морфофункціонального стану клітин крові під впливом MI-1 на тлі хронічного експериментального холангіту (порівняно з преднізолоном, який є традиційним гормональним протизапальним засобом у лікуванні запальних процесів різного генезу). Синтез МI-1 описаний у роботі [5].

Методика. Експерименти проведено на 32 білих лабораторних щурах-самцях середньою масою $198 \pm 10$ г, що утримувалися в стандартних умовах віварію Київського національного університету ім. Тараса Шевченка. Дослідження виконано відповідно до принципів біоетики, законодавчих норм та вимог згідно з положеннями “Свропейської конвенції про захист хребетних тварин, що використовуються для дослідних та наукових цілей” (Страсбург, 1986) і “Загальних етичних принципів експериментів на тваринах”, ухвалених Першим національним конгресом з біоетики (Київ, 2001). Дозвіл на проведення досліджень 
затверджений протоколом № 35 від 19 квітня 2017 р. Комісії з питань біоетики Навчальнонаукового центру “Інститут біології та медицини” Київського національного університету ім. Тараса Шевченка.

Хронічний холангіт моделювали щотижневим введенням інтрагастрально протягом 4 тижнів $\alpha$-нафтилізотіоціанату (ANIT, “Sigma”, США) у дозі 100 мг/кг, розчиненим у соняшниковій олії (загальний об’єм 0,1 мл). ANIT спричинює внутрішньопечінковий холестаз, гострий холестатичний гепатит, склерозивний холангіт, біліарний фіброз та цироз [6]. Внаслідок зазначеного ураження печінки зростає рівень білірубіну в плазмі крові, активність сироваткових амінотрансфераз та лужної фосфатази [5], які є маркерами хронічного склерозивного холангіту людини [1, 3].

MI-1 застосовували перорально у дозі 2,7 мг/кг, розчиненим у соняшниковій олії (загальний об’єм 0,1 мл), 5 днів на тиждень протягом 4 тижнів. Преднізолон (розчин для ін'єкцій, “БіоФарма”, Україна) - препарат порівняння, вводили внутрішньоочеревинно в дозі 0,7 мг/кг у фізіологічному розчині в ті ж терміни, що і МI-1. Було сформовано чотири дослідні групи (по вісім тварин у кожній групі): 1 - контроль; 2 - холангіт; 3 - холангіт + + МI-1; 4 - холангіт + преднізолон.

Кров для аналізу у щурів після $\mathrm{CO}_{2}$-інгаляційної евтаназії забирали з пахової вени через 24 год після останнього введення досліджуваних речовин. Показники крові (кількість еритроцитів, концентрація гемоглобіну в крові, гематокрит, середній об’єм еритроцита MCV, середній вміст гемоглобіну в еритроциті - MCH, середня концентрація гемоглобіну в еритроциті - МСНС, кількість лейкоцитів і тромбоцитів) визначали загальноприйнятими методами. Диференційний аналіз лейкограм здійснювали на мазках крові, забарвлених за Паппенгеймом, підраховуючи 200 лейкоцитів (базофільні, еозинофільні і нейтрофільні гранулоцити, лімфоцити, моноцити).

Статистичну обробку результатів виконували за допомогою програми SPSS 16,0 для Windows. За результатами тесту Шапіро-Уілка встановлено, що показники крові щурів мають ненормальний розподіл в одній з груп порівняння, тому для оцінки різниці між їх значеннями використовували критерій Крускала-Волліса для множинних порівнянь 3 подальшим застосуванням непараметричного критерію Манна-Уітні. Різницю вважали вірогідною при $P<0,05$.

Результати дослідження та їх обговорення. У крові щурів з ANIT-індукованим хронічним холангітом спостерігали лейкоцитоз - загальна кількість лейкоцитів зростала в середньому на 40 \% (табл. 1, $p=0,009)$. Лейкоцитоз спричинений підвищенням вмісту еозинофільних гранулоцитів на $65 \%$, лімфоцитів на $39 \%(p=0,024)$ і моноцитів у 5,4 раза $(p<0,001)$. Такі зміни є характерними гематологічними ускладненнями хронічних захворювань, у тому числі й хронічного холангіту [7], і відображають залучення різних типів лейкоцитів до прогресії захворювання та його хронізації. Акумуляція активованих Т-лімфоцитів у перипортальній зоні призводить до надмірної експресії і вивільнення гранзимів і перфоринів, наслідком чого є пошкодження цілісності мембран холангіоцитів і їх некроз та апоптоз [8]. Одночасно у пацієнтів спостерігається лімфоцитоз у крові із підвищеним вмістом як Т-, так і В-лімфоцитів.

Виявлена нами еозинофілія у крові (див. табл. 1) вказує на акумулювання еозинофілів у перипортальній зоні і характеризує хронізацію запального процесу [8]. Щільна еозино- 
фільна інфільтрація жовчних проток характерна для рідкісного варіанта еозинофільного холангіту із звуженням просвіту проток, їх фіброзом і обструкцією, яка супроводжується лейкоцитозом і істотною еозинофілією у крові (кількість еозинофілів підвищується більше ніж утричі), а також підвищеною продукцією IgM В-лімфоцитами [9]. Еозинофільний варіант хронічного холангіту дає гарну відповідь на нестероїдну протизапальну терапію, що добре корелює з нашими результатами, оскільки вміст еозинофільних гранулоцитів нормалізується після застосування преднізолону (див. табл. 1).

Моноцити та нейтрофіли першими реагують на розвиток запалення [10]. На початкових стадіях запалення активовані тканинні макрофаги (які диференціюються із моноцитів крові) активно синтезують прозапальні цитокіни, у тому числі IL-1 $\beta$, який спричинює надмірну проліферацію і диференціювання попередників нейтрофілів у кістковому мозку, вивільнення останніх у кров, що супроводжується нейтрофільозом у крові, подальшим підвищенням концентрації IL-1 $\beta$ (синтезують моноцити, нейтрофіли та інші активовані клітини), який є пірогеном і зумовлює підвищення температури тіла хворого. Обидва цих клінічних симптоми є раннім маркером запального процесу в організмі. Пухлиноасоційовані моноцити, лімфоцити, еозинофіли та нейтрофіли є основними активаторами запалення у сайті трансформації клітин і відіграють провідну роль у системній запальній відповіді під час розвитку неопластичних захворювань, а також прогресії пухлини [11]. Результати наших попередніх досліджень доводять залученість моноцитів крові до прогресії експериментального колоректального канцерогенезу [12]. Різке зростання кількості моноцитів у крові (див. табл. $1, p<0,001$ ) на тлі ANIT-індукованого хронічного холангіту підтверджує

Таблищя 1. Загальний вміст і склад лейкоцитів крові щурів у нормі, за розвитку експериментального хронічного холангіту та його корекції похідним піролу МІ-1 або преднізолоном $(M \pm m)$

\begin{tabular}{|c|c|c|c|c|c|}
\hline \multirow[b]{2}{*}{ Показник } & \multirow[b]{2}{*}{ Од. вимір. } & \multicolumn{4}{|c|}{ Група } \\
\hline & & Контроль & $\begin{array}{c}\text { Хронічний } \\
\text { холангіт }\end{array}$ & $\begin{array}{c}\text { Хронічний } \\
\text { холангіт + MI-1 }\end{array}$ & $\begin{array}{c}\text { Хронічний холангіт }+ \\
\text { + преднізолон }\end{array}$ \\
\hline Лейкоцити & $\times 10^{9} /$ Л & $17,77 \pm 0,67$ & $25,01 \pm 1,2^{*}$ & $22,22 \pm 1,64$ & $18,78 \pm 2,17$ \\
\hline $\begin{array}{l}\text { Еозинофільні } \\
\text { гранулоцити }\end{array}$ & $\begin{array}{c}\% \\
\times 10^{9} / \text { л }\end{array}$ & $\begin{array}{l}3,13 \pm 0,61 \\
0,51 \pm 0,16\end{array}$ & $\begin{array}{c}3,5 \pm 0,42 \\
0,83 \pm 0,17^{*}\end{array}$ & $\begin{array}{l}3,13 \pm 0,23 \\
0,68 \pm 0,05\end{array}$ & $\begin{array}{c}2 \pm 0,71 \\
0,37 \pm 0,11\end{array}$ \\
\hline $\begin{array}{l}\text { Паличкоядерні } \\
\text { нейтрофільні } \\
\text { гранулоцити }\end{array}$ & $\begin{array}{c}\% \\
\times 10^{9} / \text { л }\end{array}$ & $\begin{array}{l}2,63 \pm 0,5 \\
0,6 \pm 0,07\end{array}$ & $\begin{array}{l}2,38 \pm 0,53 \\
0,57 \pm 0,12\end{array}$ & $\begin{array}{c}2,5 \pm 0,73 \\
0,56 \pm 0,26\end{array}$ & $\begin{array}{c}3,4 \pm 1,36 \\
0,64 \pm 0,24\end{array}$ \\
\hline $\begin{array}{l}\text { Сегментоядерні } \\
\text { нейтрофільні } \\
\text { гранулоцити }\end{array}$ & $\begin{array}{c}\% \\
\times 10^{9} / \text { л }\end{array}$ & $\begin{array}{c}16 \pm 1,16 \\
2,91 \pm 0,31\end{array}$ & $\begin{array}{c}10,63 \pm 1,19 * \\
2,72 \pm 0,49\end{array}$ & $\begin{array}{c}10,13 \pm 1,34^{*} \\
2,23 \pm 0,47^{*}\end{array}$ & $\begin{array}{c}10,4 \pm 1,89 \\
2,01 \pm 0,36^{*}\end{array}$ \\
\hline Лімфоцити & $\begin{array}{c}\% \\
\times 10^{9} / \text { л }\end{array}$ & $\begin{array}{l}75,25 \pm 1,62 \\
13,35 \pm 0,96\end{array}$ & $\begin{array}{l}75,25 \pm 1,46 \\
18,53 \pm 1,32^{*}\end{array}$ & $\begin{array}{l}75,38 \pm 1,43 \\
16,73 \pm 1,34\end{array}$ & $\begin{array}{c}75,4 \pm 4,15 \\
14,09 \pm 2,29\end{array}$ \\
\hline Моноцити & $\begin{array}{c}\% \\
\times 10^{9} / \text { л }\end{array}$ & $\begin{array}{c}3 \pm 0,6 \\
0,4 \pm 0,11\end{array}$ & $\begin{array}{c}8,13 \pm 0,77^{*} \\
2,36 \pm 0,2^{*}\end{array}$ & $\begin{array}{l}8,88 \pm 0,67^{*} \\
2,02 \pm 0,24^{*}\end{array}$ & $\begin{array}{c}8,8 \pm 2,15^{*} \\
1,67 \pm 0,31^{*}\end{array}$ \\
\hline
\end{tabular}

* $p<0,05$ порівняно 3 контрольною групою. ${ }^{*} p<0,05$ порівняно з групою хронічного холангіту. 
залученість цих клітин до патологічного процесу. Результати досліджень різних запальних захворювань свідчать про те, що моноцити активно залучені до прогресії таких захворювань, як ожиріння, атеросклероз, нейродегенеративні, обструктивні ураження легень і печінки. А підвищена кількість моноцитів у крові є біомаркером несприятливого прогнозу перебігу фібротичних захворювань і короткої тривалості життя хворих [13], тому регуляція кількості цих клітин вкрай важлива для виживання хворих.

Введення похідного піролу МI-1 здоровим тваринам у дозах, встановлених як ефективні [5], не спричиняло змін кількісного та якісного складу клітин крові, які свідчили б про розвиток побічних реакцій експериментальної терапії [14]. Водночас важливими несприятливими наслідками тривалої терапії кортикостероїдами є синдром Кушинга, остеопороз, катаракта, психоз, диспепсія та імуносупресія, що призводить до серйозних інфекційних ускладнень [15].

Введення MI-1 щурам з ANIT-індукованим хронічним холангітом сприяло частковій нормалізації кількості лейкоцитів у крові в основному за рахунок нормалізації кількості лімфоцитів (зниження на 10 \%) і еозинофільних гранулоцитів (зниження на 20 \%) порівняно з групою хронічного холангіту та нейтрофільних гранулоцитів (зменшення на 23 \%) порівняно з контролем. У той же час кількість моноцитів залишалася підвищеною в 5 разів

Таблиия 2. Морфофункціональний стан еритроцитів крові щурів у нормі, за розвитку експериментального хронічного холангіту та його корекції похідним піролу МІ-1 або преднізолоном $(M \pm m)$

\begin{tabular}{|l|c|c|c|c|}
\hline \multirow{2}{*}{\multicolumn{1}{|c|}{ Показник }} & \multicolumn{3}{|c|}{ Група } \\
\cline { 2 - 5 } & Контроль & $\begin{array}{c}\text { Хронічний } \\
\text { холангіт }\end{array}$ & $\begin{array}{c}\text { Хронічний } \\
\text { холангіт + МІ-1 }\end{array}$ & $\begin{array}{c}\text { Хронічний } \\
\text { холангіт + преднізолон }\end{array}$ \\
\hline Концентрація & & & & \\
гемоглобіну, г/л & $146,16 \pm 1,94$ & $136,44 \pm 2,52^{*}$ & $133,39 \pm 2,93^{*}$ & $139,13 \pm 5,12$ \\
$\mathrm{RBC}, \times 10^{12} /$ л & $7,91 \pm 0,07$ & $7,66 \pm 0,09^{*}$ & $7,76 \pm 0,15$ & $7,87 \pm 0,1$ \\
$\mathrm{MCH,} \mathrm{пг}$ & $18,47 \pm 0,12$ & $17,81 \pm 0,22^{*}$ & $17,18 \pm 0,11^{*}$ & $17,66 \pm 0,44$ \\
$\mathrm{MCHC,} \mathrm{г/л}$ & $306,33 \pm 2,26$ & $293,14 \pm 2,43^{*}$ & $285,09 \pm 2,79^{*}$ & $291,34 \pm 6,92^{*}$ \\
$\mathrm{Ht}, \%$ & $47,71 \pm 0,51$ & $46,53 \pm 0,62$ & $46,8 \pm 1,03$ & $47,7 \pm 0,82$ \\
$\mathrm{MCV}$, фл & $60,32 \pm 0,27$ & $60,76 \pm 0,32$ & $60,29 \pm 0,37$ & $60,62 \pm 0,56$ \\
\hline
\end{tabular}

* $p<0,05$ порівняно з контрольною групою.

Таблиия 3. Кількість ретикулоцитів і тромбоцитів у крові щурів у нормі, за розвитку експериментального хронічного холангіту та його корекції похідним піролу МI-1 або преднізолоном $(M \pm m)$

\begin{tabular}{|c|c|c|c|c|}
\hline \multirow{2}{*}{\multicolumn{1}{|c|}{ Показник }} & \multicolumn{4}{|c|}{ Група } \\
\cline { 2 - 5 } & Контроль & $\begin{array}{c}\text { Хронічний } \\
\text { холангіт }\end{array}$ & $\begin{array}{c}\text { Хронічний } \\
\text { холангіт + МІ-1 }\end{array}$ & $\begin{array}{c}\text { Хронічний холангіт + } \\
\text { преднізолон }\end{array}$ \\
\hline $\begin{array}{l}\text { Ретикулоцити, } \times 10^{12} / л \\
\text { Тромбоцити, } \times 10^{9} / \mathrm{л}\end{array}$ & $\begin{array}{c}0,17 \pm 0,01 \\
889,91 \pm 32,38\end{array}$ & $\begin{array}{c}0,29 \pm 0,02^{*} \\
1315,88 \pm 82,73^{*}\end{array}$ & $\begin{array}{c}0,51 \pm 0,03^{*} \# \\
1034,61 \pm 83,72 \#\end{array}$ & $\begin{array}{c}0,3 \pm 0,02^{*} \\
1182,41 \pm 104,18^{*}\end{array}$ \\
\hline
\end{tabular}

${ }^{*} p<0,05$ порівняно з контрольною групою. ${ }^{*} p<0,05$ порівняно з групою хронічного холангіту. 
$(p<0,001)$, але зменшувалася на $15 \%$ порівняно з групою хронічного холангіту. Ефекти MI-1 аналогічні до ефектів препарату порівняння преднізолону (див. табл. 1), але низька гематоксичність досліджуваної сполуки надає йому переваги у використанні [14].

Одним із ускладнень розвитку запалення в організмі є анемія, яка обумовлена пригнічувальним впливом на еритропоез прозапальних цитокінів, а також їх слабкою гемолітичною дією, порушенням транспорту іонів заліза, вітаміну $\mathrm{B}_{12}$ [4]. Внаслідок таких змін в організмі розвивається поліфакторна анемія іноді з надлишком ретикулоцитів, як індикатора активації відновних процесів [12]. За перебігу ANIT-індукованого хронічного холангіту спостерігалося незначне зниження концентрації гемоглобіну в крові $(p=0,049)$, кількості еритроцитів, середнього вмісту (MCH) і середньої концентрації (МСНС) гемоглобіну в еритроциті (табл. 2) на тлі зростання в 1,7 раза кількості ретикулоцитів (табл. 3, $p=0,001$ ), що підтверджує розвиток багатофакторної анемії. MI-1 відновлював кількість еритроцитів у крові (див. табл. 2), стимулюючи процеси утворення еритроцитів, що підверджується зростанням втричі кількості ретикулоцитів порівняно з контролем (див. табл. $3, p<0,001)$. Водночас концентрація гемоглобіну в крові, середній вміст $(\mathrm{MCH})$ і середня концентрація гемоглобіну (MCHC) в еритроциті залишалися зниженими (див. табл. $2, p=0,004, p=0,016, p<0,001$ відповідно), що пов'язано із прискоренням їх диференціювання в кістковому мозку.

Розвиток ANIT-індукованого хронічного холангіту супроводжується зростанням кількості тромбоцитів у крові на 48 \% (див. табл. $3, p=0,002)$. Тромбоцитоз часто асоційований із запаленням, внаслідок активації тромбоцитопоезу прозапальними цитокінами і ростовими факторами, серед яких VEGF. Одночасно наявність ростових факторів у тромбоцитах активує сполучнотканинні фібробласти до відкладання позаклітинного матриксу і наростання фіброзу, саме тому тромбоцитоз пов'язують з прогресією захворювання [16]. MI-1, інгібітор рецепторзв'язаної кінази фактору росту судин (VEGR-кінази, Vascular Endothelial Growth Factor Receptor) [5, 14], нормалізує кількість тромбоцитів у крові, зменшуючи їх кількість більше ніж на 20 \% порівняно з групою хронічного холангіту $(p=0,038)$. Такий нормалізуючий вплив МI-1 переважає ефекти преднізолону, після введення якого кількість тромбоцитів зберігається підвищеною на 33 \% $(p=0,015)$ порівняно 3 контролем, і забезпечує більш ефективне гальмування розвитку фібротичних ускладнень [5].

Підсумовуючи вищевикладені результати, можна стверджувати, що похідне піролу MI-1, що діє як панспецифічний інгібітор протеїнкіназ, гальмує розвиток запалення, що виникає за ANIT-індукованого хронічного холангіту. Це підтверджується нормалізацією загальної кількості лейкоцитів у крові за рахунок еозинофільних і нейтрофільних гранулоцитів та лімфоцитів. Досліджуване похідне стимулює відновлення кількості еритроцитів у крові і пригнічує залучення тромбоцитів до патологічного процесу, що разом із низькою токсичністю надає йому переваги як потенційного терапевтичного чинника.

\section{ЦИТОВАНА ЛІТЕРАТУРА}

1. Galoosian A., Hanlon C., Zhang J., Holt E.W., Yimam K.K. Clinical updates in primary biliary cholangitis: trends, epidemiology, diagnostics, and new therapeutic approaches. J. Clin. Transl. Hepatol. 2020. 8, № 1. P. 49-60. https://doi.org/10.14218/JCTH.2019.00049 
2. Pinto C., Giordano D.M., Maroni L., Marzioni M. Role of inflammation and proinflammatory cytokines in cholangiocyte pathophysiology. Biochim. Biophys. Acta. Mol. Basis Dis. 2018. 1864, Iss. 4, Pt. B. P. 12701278. https://doi.org/10.1016/j.bbadis.2017.07.024

3. Gidwaney N.G., Pawa S., Das K.M. Pathogenesis and clinical spectrum of primary sclerosing cholangitis. World J. Gastroenterol. 2017. 23, № 14. P. 2459-2469. https://doi.org/10.3748/wjg.v23.i14.2459

4. Weiss G., Ganz T., Goodnough L.T. Anemia of inflammation. Blood. 2019. 133, № 1. P. 40-50. https://doi. org/10.1182/blood-2018-06-856500

5. Кузнєцова Г.М., Дзюбенко Н.В., Линчак О.В., Тихонюк О.І., Мілохов Д.С., Хиля О.В., Рибальченко В.К. Гепатопротекторна дія інгібітора протеїнкіназ 1-(4-Сl-бензил)-3-хлор-4-( $\mathrm{CF}_{3}$-феніламіно)-1Hпірол-2,5-діону за умов розвитку гострого холангіту щурів. Допов. Нащ. акад. наук Укр. 2018. № 5. C. 83-90. https://doi.org/10.15407/dopovidi2018.05.083

6. Fickert P., Pollheimer M.J., Beuers U., Lackner C., Hirschfield G., Housset C., Keitel V., Schramm C., Marschall H.-U., Karlsen T.H., Melum E., Kaser A., Eksteen B., Strazzabosco M., Manns M., Trauner M. Characterization of animal models for primary sclerosing cholangitis (PSC). J. Hepatol. 2014. 60, № 6. P. 1290-1303. https://doi.org/10.1016/j.jhep.2014.02.006

7. Snook J.A., Chapman R.W., Sachdev G.K., Heryet A., Kelly P.M., Fleming K.A., Jewell D.P. Peripheral blood and portal tract lymphocyte populations in primary sclerosing cholangitis. J. Hepatol. 1989. 9, № 1. P. 36-41. https://doi.org/10.1016/0168-8278(89)90073-1

8. Tsuneyama K., Baba H., Morimoto Y., Tsunematsu T., Ogawa H. Primary biliary cholangitis: its pathological characteristics and immunopathological mechanisms. J. Med. Invest. 2017. 64, № 1.2. P. 7-13. https://doi. org/10.2152/jmi.64.7

9. Fragulidis G.P., Vezakis A.I., Kontis E.A., Pantiora E.V., Stefanidis G.G., Politi A.N., Koutoulidis V.K., Mela M.K., Polydorou A.A. Eosinophilic cholangitis - a challenging diagnosis of benign biliary stricture: a case report. Medicine (Baltimore). 2016. 95, № 1. e2394. https://doi.org/10.1097/MD.0000000000002394

10. Byelinska I.V., Kuznietsova H.M., Dziubenko N.V., Lynchak O.V., Rybalchenko T.V., Prylutskyy Yu.I. , Kyzyma O.A., Ivankov O., Rybalchenko V.K., Ritter U. Effect of $\mathrm{C}_{60}$ fullerenes on the intensity of colon damage and hematological signs of ulcerative colitis in rats. Mater. Sci. Eng. C Mater. Biol. Appl. 2018. 93. P. 505-517. https://doi.org/10.1016/j.msec.2018.08.033

11. Kapellos T.S., Bonaguro L., Gemünd I, Reusch N., Reusch N., Saglam A., Hinkley E.R., Schultze J.L. Human monocyte subsets and phenotypes in major chronic inflammatory diseases. Front. Immunol. 2019. 10. 2035. https://doi.org/10.3389/fimmu.2019.02035

12. Byelinska I.V., Lynchak O.V., Rybalchenko T.V., Yablonska S.V., Bahurynska O.M., Rybalchenko V.K. Morphofunctional parameters of blood cells of a rat with 1,2-dimethylhydrazine-induced colon carcinogenesis. Cytol. Genet. 2015. 49, № 3. P. 158-164. https://doi.org/10.3103/S0095452715030044

13. Scott M.K.D, Quinn K., Li Q., Carroll R., Warsinske H., Vallania F., Chen S., Carns M.A., Aren K., Sun J., Koloms K., Lee J., Baral J., Kropski J., Zhao H., Herzog E., Martinez F.J., Moore B.B., Hinchcliff M., Denny J., Kaminski N., Herazo-Maya J.D., Shah N.H., Khatri P. Increased monocyte count as a cellular biomarker for poor outcomes in fibrotic diseases: a retrospective, multicentre cohort study. Lancet Respir. Med. 2019. 7. P. 497-508. https://doi.org/10.1016/S2213-2600(18)30508-3

14. Бєлінська І.В., Рибальченко Т.В., Цивінська С.М., Рибальченко В.К. Гематологічні ефекти інгібітора протеїнкіназ похідного малеіміду і 5-фторурацилу. Фізіол. журн. 2017. 63, № 4. С. 37-47. https://doi. org $/ 10.15407 /$ fz63.04.037

15. Joshi N., Rajeshwari K. Deflazacort. J. Postgrad. Med. 2009. 55, Iss. 4. P. 296-300. https:/doi.org/ 10.4103/0022-3859.58942

16. Lisman T., Luyendyk J.P. Platelets as modulators of liver diseases. Semin. Thromb. Hemost. 2018. 44, № 2. P. 114-125. https://doi.org/10.1055/s-0037-1604091

Надійшло до редакції 09.04.2021

\section{REFERENCES}

1. Galoosian, A., Hanlon, C., Zhang, J., Holt, E. W. \& Yimam, K. K. (2020). Clinical updates in primary biliary cholangitis: trends, epidemiology, diagnostics, and new therapeutic approaches. J. Clin. Transl. Hepatol., 8, No. 1, pp. 49-60. https://doi.org/10.14218/JCTH.2019.00049 
2. Pinto, C., Giordano, D. M., Maroni, L. \& Marzioni M. (2018). Role of inflammation and proinflammatory cytokines in cholangiocyte pathophysiology. Biochim. Biophys. Acta. Mol. Basis. Dis., 1864, Iss. 4, Pt. B, pp. 1270-1278. https://doi.org/10.1016/j.bbadis.2017.07.024

3. Gidwaney, N. G., Pawa, S. \& Das K. M. (2017). Pathogenesis and clinical spectrum of primary sclerosing cholangitis. World. J. Gastroenterol., 23, No. 14, pp. 2459-2469. https://doi.org/10.3748/wjg.v23.i14.2459

4. Weiss, G., Ganz, T. \& Goodnough, L. T. (2019). Anemia of inflammation. Blood, 133, No. 1, pp. 40-50. https:// doi.org/10.1182/blood-2018-06-856500

5. Kuznietsova, H. M., Dziubenko, N. V., Lynchak, O. V., Tykhoniuk, O. I., Milokhov, D. S., Khilya, O. V. \& Rybalchenko, V. K. (2018). Hepatoprotective effect of protein kinase inhibitor 1-(4-Cl-benzyl)-3-chloro-4( $\mathrm{CF}_{3}$-phenylamino)-1H-pyrrole-2,5-dione on rats' acute cholangitis. Dopov. Nac. akad. nauk Ukr., No. 5, pp. 83-90. https://doi.org/10.15407/dopovidi2018.05.083

6. Fickert, P., Pollheimer, M. J., Beuers, U., Lackner, C., Hirschfield, G., Housset, C., Keitel, V., Schramm, C., Marschall, H.-U., Karlsen, T.H., Melum, E., Kaser, A., Eksteen, B., Strazzabosco, M., Manns, M. \& Trauner, M. (2014). Characterization of animal models for primary sclerosing cholangitis (PSC). J. Hepatol., 60, No. 6, pp. 1290-1303. https://doi.org/10.1016/j.jhep.2014.02.006

7. Snook, J. A., Chapman, R. W., Sachdev, G. K., Heryet, A., Kelly, P. M., Fleming, K. A. \& Jewell D. P. (1989). Peripheral blood and portal tract lymphocyte populations in primary sclerosing cholangitis. J. Hepatol., 9, No. 1, pp. 36-41. https://doi.org/10.1016/0168-8278(89)90073-1

8. Tsuneyama, K., Baba, H., Morimoto, Y., Tsunematsu, T. \& Ogawa H. (2017). Primary biliary cholangitis: its pathological characteristics and immunopathological mechanisms. J. Med. Invest., 64, No. 1.2, pp. 7-13. https://doi.org/10.2152/jmi.64.7

9. Fragulidis, G. P., Vezakis, A. I., Kontis, E. A., Pantiora, E. V., Stefanidis, G. G., Politi, A. N., Koutoulidis, V. K., Mela, M. K. \& Polydorou, A. A. (2016). Eosinophilic cholangitis - a challenging diagnosis of benign biliary stricture: a case report. Medicine (Baltimore), 95, No. 1, e2394. https://doi.org/10.1097/ MD.0000000000002394

10. Byelinska, I. V., Kuznietsova, H. M., Dziubenko, N. V., Lynchak, O. V., Rybalchenko, T. V., Prylutskyy, Yu. I., Kyzyma, O. A., Ivankov, O., Rybalchenko, V. K. \& Ritter U. (2018). Effect of $\mathrm{C}_{60}$ fullerenes on the intensity of colon damage and hematological signs of ulcerative colitis in rats. Mater. Sci. Eng. C Mater. Biol. Appl., 93, pp. 505-517. https://doi.org/10.1016/j.msec.2018.08.033

11. Kapellos, T. S., Bonaguro, L., Gemünd, I., Reusch, N., Saglam, A., Hinkley, E. R. \& Schultze J. L. (2019). Human monocyte subsets and phenotypes in major chronic inflammatory diseases. Front. Immunol., 10, 2035. https://doi.org/10.3389/fimmu.2019.02035

12. Byelinska, I. V., Lynchak, O. V., Rybalchenko, T. V., Yablonska, S. V., Bahurynska, O. M. \& Rybalchenko, V. K. (2015). Morphofunctional parameters of blood cells of a rat with 1,2-dimethylhydrazine-induced colon carcinogenesis. Cytol. Genet., 49, No. 3, pp. 158-164. https://doi.org/10.3103/S0095452715030044

13. Scott, M. K. D., Quinn, K., Li, Q., Carroll, R., Warsinske, H., Vallania, F., Chen, S., Carns, M. A., Aren, K., Sun, J., Koloms, K., Lee, J., Baral, J.,, Kropski, J., Zhao, H., Herzog, E., Martinez, F. J., Moore, B. B., Hinchcliff, M., Denny, J., Kaminski, N., Herazo-Maya, J. D., Shah, N. H. \& Khatri, P. (2019). Increased monocyte count as a cellular biomarker for poor outcomes in fibrotic diseases: a retrospective, multicentre cohort study. Lancet. Respir. Med., 7, pp. 497-508. https://doi.org/10.1016/S2213-2600(18)30508-3

14. Byelinska, I. V., Rybalchenko, T. V., Tsyvinska, S. M. \& Rybalchenko, V. K. (2017). The hematological effects of the protein kinases inhibitor maleimide derivative and 5-fluorouracil. Fiziol Zh., 63, No. 4, pp. 37-47 (in Ukrainian). https://doi.org/10.15407/fz63.04.037

15. Joshi, N. \& Rajeshwari, K. (2009). Deflazacort. J. Postgrad. Med., 55, Iss. 4, pp. 296-300. https://doi. org/10.4103/0022-3859.58942

16. Lisman, T. \& Luyendyk, J. P. (2018). Platelets as modulators of liver diseases. Semin. Thromb. Hemost., 44, No. 2, pp. 114-125. https://doi.org/10.1055/s-0037-1604091

Received 09.04.2021 
I.V. Byelinska, https://orcid.org/0000-0003-3551-1161

H.M. Kuznietsova, https://orcid.org/0000-0002-1296-1007

N.V. Dziubenko, https://orcid.org/0000-0002-2998-4168

Y.V. Savych

D.S. Milokhov, https://orcid.org/0000-0002-7493-3634

O.V. Khilya, https://orcid.org/0000-0002-1155-0740

T.V. Rybalchenko

Taras Shevchenko National University of Kyiv

E-mail: byelinska@univ.kiev.ua

\section{APPLICATION OF 1-(4-Cl-BENZYL)-3-Cl-4-( $\mathrm{CF}_{3}$-PHENYLAMINO)- $1 H$-PYRROLE-2,5-DIONE AS A PANSPECIFIC PROTEIN KINASE INHIBITOR FOR INHIBITION OF HEMATOLOGICAL COMPLICATIONS IN EXPERIMENTAL CHRONIC CHOLANGITIS IN RATS}

The effect of a a panspecific inhibitor of pyrrole derivatives (1-(4-Cl-benzyl)-3-Cl-4-( $\mathrm{CF}_{3}$-phenylamino)-1Hpyrrole-2,5-dione, MI-1), synthesized at the Kyiv National Taras Shevchenko University, on hematological manifestations of experimental $\alpha$-anaphthyl isothiocyanate-induced chronic cholangitis is studied. It is found that MI-1 reduces the level of inflammation, which is confirmed by the normalization of the total number of leukocytes in blood due to a decrease in the number of eosinophilic and neutrophilic granulocytes and lymphocytes involved in the development of experimental chronic cholangitis. MI-1 restores the number of erythrocytes in blood through the activation of erythropoiesis, that is evident by an increase in the number of reticulocytes in blood of rats with experimental cholangitis. MI-1 normalizes the number of platelets in blood most likely due to inhibition of platelet formation in bone marrow, activated by the development of an inflammatory process in liver. MI-1 reduces the level of hematological complications of experimental chronic cholangitis in rats and with proven low overall and hematoxicity and hepatoprotective effect is promising for further research as a compound with anti-inflammatory activity.

Keywords: pirole derivative, protein kinases inhibitor, chronic cholangitis, erythrocytes, leukocytes, platelets. 